\title{
E-Trust and Website Quality Can Improve E-Loyalty Through E-Satisfaction
}

\author{
Samlatul Izzah* Heri Pratikto Sutrisno \\ Study Program of Management, Postgraduate, Universitas Negeri Malang \\ Jl. Semarang No.5, Malang 65145, Jawa Timur, Indonesia
}

\begin{abstract}
This research aims to know the effect of E-Trust and Website Quality to E-Loyalty through E-Satisfaction. The research population is obtained from Tokopedia users who transact at least 2 times. The population sample taken in the research is about 156 respondents. Within the data collection, this research employs questionnaire. From the path analysis method, it shows that E-Trust and Website Quality directly affect to E-Loyalty or indirectly affect to E-Satisfaction. This research concludes that E-Trust and Website Quality both directly and indirectly affect to build the E-Loyalty through their E-Satisfaction. In last, based on the research result, it recommends to create new innovations to boost E-Satisfaction.
\end{abstract}

Keywords: E-Trust, Website Quality, E-Satisfaction, E-Loyalty

DOI: $10.7176 / \mathrm{EJBM} / 11-12-19$

Publication date: April $30^{\text {th }} 2019$

\section{Introduction}

The development of internet currently brings big influence toward society in some life aspects including business. In Indonesia, some enterprises have introduced a system called electronic commerce. It is a form of business transaction through internet media.. E-commerce is an activity conducting business transaction in online through internet media and devices integrated with the internet (Laudon, 2012). E-commerce is the result from trend development in society as one of efforts to meet human needs in more effective and efficient. One of popular ecommerce in Indonesia is C2C (Customer to Customer) or well-known as buying and selling site. C2C e-commerce enables the users to sell and buy each other products or services through a market place (Laudon, 2012).

In Indonesia, e-commerce enterprises which apply C2C is Tokopedia. The company built on August $17^{\text {th }} 2009$ provides facility which ease the users to sell the product only by uploading the photos and writing down the description of product. The buyers can only browse the product in some browsing selections. Tokopedia provides complete information about seller so that the buyer can compare and choose where to buy.

Each site of e-commerce competes in giving the best experience of shopping for the satisfaction of customer. One of ways to preserve business continuity in intense competition is to maintain customer satisfaction. The aim of company preserve satisfaction of customer is to maintain custumer by improving customer loyalty. In the context of e-commerce, customer's satisfaction is called e-satisfaction, whereas customer's loyalty is called eloyalty. The steps which can be done to improve e-satisfaction is by concerning e-trust of customer and website quality.

E-trust is defined as consumer confidence toward quality and reliability of the offered products and services (Garbarino \& Johnson, 1999), and the confidence about trustworthy nature, honesty and virtue possessed by ecommerce company (Gefen, 2000). whereas Wbsite quality is one of methods or website quality measurement techniques based on the perceptions of end users. Website quality can be considered as an attribute of a website that contributes to its usefulness to consumers (Gregg and Walczak, 2010). the owner of online store must give their best service by paying attention to the website quality to convince visitors and get trust and then lead to customer loyalty (Sadeh et al. 2011).

E-satisfaction affects positively toward e-loyalty, but e-loyalty will be only formed if other factors are also completed (Oliver, 1999). therefore, e-satisfaction plays an important role in e-loyalty establishment and it also has correlation with other factors (Cheng, 2014).

This research aims to analyze the effect of e-trst and website quality toward e-satisfaction and he effect toward e-loyalty. Based on the described background, the problems in this research are as follow:

1) How are the descriptions of E-trust, Website Quality, E-Loyalty and E-Satisfaction of Tokopedia customers?

2) Does E-trust affect toward E-satisfaction of Tokopedia customers?

3) Does Website Quality affect toward E-satisfaction of Tokopedia customers?

4) Does E-Satisfaction affect toward E-Loyalty of Tokopedia customers?

5) Dose E-Trust affect toward E-Loyalty of Tokopedia customers?

6) Does Website Quality affect directly toward E-Loyalty of Tokopedia customers?

7) Does Website Quality affect indirectly toward E-Loyalty through E-Satisfaction of Tokopedia customer?

8) Does E-Trust affect inderectly toward E-Loyalty through E-satisfaction of Tokopedia customer?

Based on existing theories, then proposed several hypotheses proposed in this study, namely: 
H1: E-Trust has a positive and significant effect on E-Satisfaction

$\mathrm{H} 2$ : Website Quality has a positive and significant effect on E-Satisfaction

H3: E-Satisfaction has a positive and significant effect on E-Loyalty

H4: E-Trust has a positive and significant direct effect on E-Loyalty

H5: Website Quality has a positive and significant direct effect on E-Loyalty

H6: Website Quality has a positive and significant indirect effect on E-Loyalty through E-Satisfaction

H7: E-Trust has a positive and significant indirect effect on E-Loyalty through E-Satisfaction

\section{Research Method}

This research used quantitative research method with descriptive and Explanatory research approaches.. The method of quantitative research refers to the methods to clarify the certain theories by examining the relation between variables (Creswell, 2013). Descriptive approach was used to describe the circumstances of each variable of E-Trust ( $\left.\mathrm{x}_{1}\right)$, Website quality $\left(\mathrm{x}_{2}\right)$, E-loyalty (y), dan E-satisfaction (z). Explanatory Research is a research which aims to explain the ralation between variable and phenomenon of research (Cooper \& Schinder, 2011).

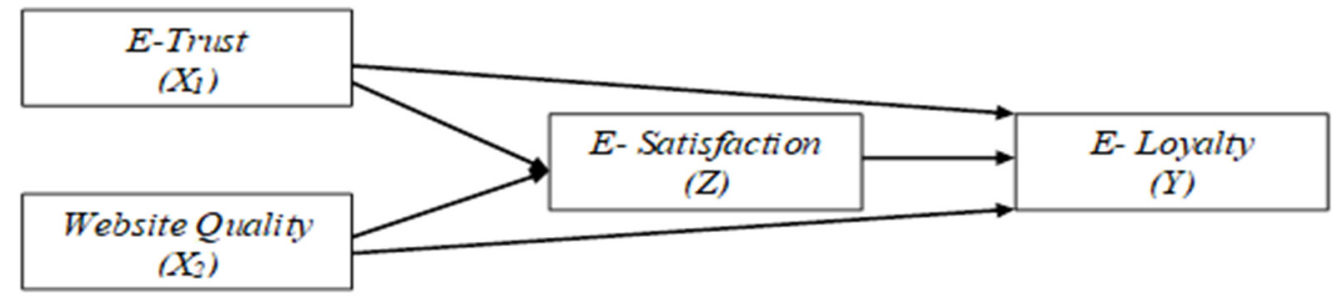

Figure 2.1 Research Design

\subsection{Population and Sample}

Population is as generalization area consisting of abject or subject which has certain quality and characteristic determined by researcher to be studies, processed and drawn the conclusion (Sugiyono, 2014). The population in this study were unknown numbers of Tokopedia users. The sample used in this study were 130 people who had made product purchase transactions at Tokopedia at least twice. The sampling method used purposive sampling. Data were obtained from distributing questionnaires using Google Form media. The result of trial showed that questionnaire is valid and reliable.

\subsection{Data Analysis}

After the data are collected, the researcher will analyze the data. This research analysis uses method of descriptive and inferential analysis. In the data analysis process, the researcher describes and figures the collected data without having intention to draw general conclusion (Sugiyono, 2014). This descriptive analysis refers to the descriptive variable of research: E-Trust $\left(\mathrm{X}_{1}\right)$, Website Quality $\left(\mathrm{X}_{2}\right)$, Customer's Satisfaction (Z), and Customer's Loyalty (Y). Inferential analysis is a research method that analyze the sample data and make generalization (valid generally) in population.

\subsection{Result of Descriptive Analysis}

1. Variable of E-Trust (X1)

Based on table 2.3.1, it shows that the average of E-Trust variable has average of 3.77. the class interval is categorized $3.40<(\mathrm{ET}, \mathrm{WQ}, \mathrm{ES}, \mathrm{EL}) \leq 4.20$. It can be defined that the assessment of respondents toward E-Trust of Tokopedia is high. 
Table 2.3.1 Frequency Distribution of E-Trust $\left(\mathrm{X}_{1}\right)$ Variable

\begin{tabular}{lll}
\hline No. & Questions & Average \\
\hline ET1 & Tokopedia is one of the biggest selling and buying sites in Indonesia & 4,28 \\
\hline ET2 & Product and service offered by Tokepedia are complete & 3,97 \\
\hline ET3 & Tokopedia updates in giving new information & 4,21 \\
\hline ET4 & Transaction in Tokopedia is easy to carry out & 3,83 \\
\hline ET5 & I am sure that Tokopedia will maintain my personal information security & 3,76 \\
\hline ET6 & I believe that Tokopedia will not misuse my personal information & 3,75 \\
\hline ET7 & Tokopedia is able to secure customer transaction from the fraud & 3,40 \\
\hline ET8 & Tokopedia will responsible over he problems in transaction & 3,47 \\
\hline ET9 & The delivery is not more than the estimation & 3,72 \\
\hline ET10 & Received product is accordance with the description of seller & 3,79 \\
\hline ET11 & There is return of goods when the product received is wrong / damaged & 3,37 \\
\hline Total of average & & 3.77 \\
\hline
\end{tabular}

Source: Data is processed by the researcher, 2019

2. Variable of Website Quality (X2)

Based on table 2.3.2, it shows tgat the average of Website Quality has average of 4,21. In class intervals is categorized in $3.40<(\mathrm{ET}, \mathrm{WQ}, \mathrm{ES}, \mathrm{EL}) \leq 4.20$. this can be interpreted that the value indicates that respondents' assessment of the Quality Tokopedia Website is good.

\section{Table 2.3.4 Frequency Distribution of Website Quality $\left(X_{2}\right)$ Variable}

\begin{tabular}{lll}
\hline No. & Questions & Average \\
\hline WQ1 & The dispay of website/Tokopedia is user friendly & 4,25 \\
\hline WQ2 & Tokopedia's Website displays an interesting visual design & 4,22 \\
\hline WQ3 & The steps to do transaction of Tokopedia is easy. & 3,96 \\
\hline WQ4 & Tokopedia always gives notification while releasing new information. & 4,19 \\
\hline WQ5 & There is browsing facility to ease costumer in finding product needed. & 4,27 \\
\hline WQ6 & Opening Toopedia page does not need long time & 4,13 \\
\hline WQ7 & The choice of payment method is just to facilitate customer in transactions & 3,96 \\
\hline WQ8 & $\begin{array}{l}\text { Website of Tokopedia provides customer testimony column to make it easier for me } \\
\text { to assess a product. }\end{array}$ & 4,46 \\
\hline WQ9 & $\begin{array}{l}\text { Tokopedia provides resolution center, chat as a means of communication between } \\
\text { sellers and buyers }\end{array}$ & 4,47 \\
\hline $\begin{array}{l}\text { Total of } \\
\text { average }\end{array}$ & & 4.21 \\
\hline
\end{tabular}

Source : Data is processed by the researcher, 2019

3. Variable of E-Satisfaction (Z)

Based on table 2.3.3, it shows that the average of E-Satisfaction has average of 3.30. The class intervals is categorized $2.60<(\mathrm{ET}, \mathrm{WQ}, \mathrm{ES}, \mathrm{EL}) \leq 3.40$. This can be interpreted that the Tokopedia E-Satisfaction assessment is still in the moderate category.

Table 2.3.3 Frequency Distribution of E-Satisfaction (Z) Variable

\begin{tabular}{llc}
\hline No & Question & Average \\
\hline ES1 & I am satified with the experience of shopping in Tokopedia & 3,74 \\
\hline ES2 & $\begin{array}{l}\text { Tokopedia provides various services which will give easiness for the users, such } \\
\text { us purchase train tickets, planes, top-ups, bill payments, etc. }\end{array}$ & 4,16 \\
\hline ES3 & Tokopedia often gives discount, & 3,38 \\
\hline ES4 & $\begin{array}{l}\text { Tersedianya call centre 24 jam untuk melayani konsumen coupons, free } \\
\text { shipping facilities to relieve consumers }\end{array}$ & 2,54 \\
\hline ES5 & Customer services service customer complain well and quickly & 2,72 \\
\hline Total of average & & 3.30 \\
\hline
\end{tabular}

Source : Data is processed by the researcher, 2019

4. Variable of Loyalty (Y)

Based on table 2.3.4, it shows that the average of $\mathrm{E}=$ Loyalty variable has average of 3.41. The class intervals is categorized $3.40<(\mathrm{ET}, \mathrm{WQ}, \mathrm{ES}, \mathrm{EL}) \leq 4.20$. this can be interpreted that the Tokopedia E-Loyalty user is high. 
Table 2.3.4 Frequency Distribution of E-Loyalty variable (Y)

\begin{tabular}{llc}
\hline No. & Questions & Average \\
\hline EL1 & I will revisit Tokopedia website at a later time & 3,98 \\
\hline EL2 & I will shop agi in Tokopedia & 3,51 \\
\hline EL3 & I will buy somme other products in Tokopedia website & 3,51 \\
\hline EL4 & I am willing to recommend Tokopedia to friends and relatives for online shopping & 3,52 \\
\hline EL5 & I will often use Tokopedia while shopping online & 2,51 \\
\hline $\begin{array}{l}\text { Total of } \\
\text { average }\end{array}$ & & 3.41 \\
\hline
\end{tabular}

Source : Data is processed by the researcher, 2019

First comparison

The researcher will analyze the line related to the variable of E-Trust $\left(\mathrm{X}_{1}\right)$, Website Quality $\left(\mathrm{X}_{2}\right)$, E- Satisfaction (Z):

Table 2.3.5 Anova Sub-Structure 1

ANOVA ${ }^{\mathrm{a}}$

\begin{tabular}{|cc|c|c|c|c|c|}
\hline & Model & Sum of Squares & df & Mean Square & F & Sig. \\
\hline \multirow{2}{*}{1} & Regression & 694,243 & 2 & 347,122 & 118,940 &, $000^{\mathrm{b}}$ \\
& Residual & 446,526 & 153 & 2,918 & & \\
& Total & 1140,769 & 155 & & & \\
\hline
\end{tabular}

a. Dependent Variable: $\mathrm{Z}$

b. Predictors: (Constant), X2, X1

It is seen from Sig column. On the Anova table, Sig value is 0.000 or smaller than probability value 0.05 (Sig $0.000<0.050$ ), then $\mathrm{H}_{0}$ is rejected and $\mathrm{H}_{\mathrm{a}}$ is accepted.

Table 2.3.6 Summary Sub-Structure 1

Model Summary ${ }^{b}$

\begin{tabular}{|c|c|c|c|c|}
\hline Model & $\mathrm{R}$ & R Square & Adjusted R Square & Std. Error of the Estimate \\
\hline 1 &, $780^{\mathrm{a}}$ &, 609 &, 603 & 1,708 \\
\hline
\end{tabular}

a. Predictors: (Constant), X2, X1

b. Dependent Variable: $Z$

Simultaneously, the variable of product quality (X1), Brand Image (X2), Menu Variety (X3) contribute 0.609 $(60.9 \%)$ (Value of R square and Summary table) in describing the change on the variable of E-Satisfaction $(Z)$, meanwhile the rest $39.1 \%$ is described by the other variables. On Anova table (Test F) shows that simultaneously the free variables have significant effect to the variable of E-Satisfaction $(Z)$.

Table 2.3.7 Coefficients Sub-Structure 1

Coefficients $^{\mathrm{a}}$

\begin{tabular}{|l|l|l|l|l|l|l|l|l|}
\hline \multirow{2}{*}{ Model } & Unstandardized Coefficients & Standardized Coefficients & $\mathrm{t}$ & \multicolumn{3}{|l|}{ Sig. } & \multicolumn{3}{|l|}{ Collinearity Statistics } \\
\cline { 2 - 4 } & $\mathrm{B}$ & Std. Error & Beta & & & Tolerance & VIF \\
\hline (Constant) & $-4,930$ & 1,442 & & $-3,419$ &, 001 & & \\
1 X1 &, 282 &, 034 &, 513 & 8,232 &, 000 &, 660 & 1,516 \\
X2 &, 257 &, 044 &, 361 & 5,793 &, 000 &, 660 & 1,516 \\
\hline
\end{tabular}

a. Dependent Variable: $\mathrm{Z}$

On the coefficient table of the variable of E-Trust $\left(\mathrm{X}_{1}\right)$, Website Quality $\left(\mathrm{X}_{2}\right)$, simultaneously affect to the ESatisfaction $(Z)$ which intends to test the constant significance and dependent variable. On the coefficient table, partial test / T Test shows that the variable of E-Trust $\left(\mathrm{X}_{1}\right)$, Website Quality $\left(\mathrm{X}_{2}\right)$, statistically affect significantly to the E-Satisfaction $(Z)$. This is indicated by the Sig Value. Each value is smaller than alpha 5\%, 0.000.

$\mathrm{Z}=\rho z x_{1}+\rho z x_{2}+\varepsilon_{2}$

$=0,513 x_{1}+0,361 x_{2}+0,625 \varepsilon_{2}$

Second Comparison

E-Trust (X1), Website Quality (X2), through E- Satisfaction (Z) simultaneously to E-Loyalty (Y). Here are the discussion about the line analysis related to the variables. 
Table 2.3.8 Annova Sub-Structure 2

ANOVA $^{\mathrm{a}}$

\begin{tabular}{|cc|c|c|c|c|c|}
\hline \multicolumn{2}{|c|}{ Model } & Sum of Squares & df & Mean Square & F & Sig. \\
\hline \multirow{2}{*}{1} & Regression & 822,810 & 3 & 274,270 & 137,122 &, $000^{\mathrm{b}}$ \\
& Residual & 304,029 & 152 & 2,000 & & \\
& Total & 1126,840 & 155 & & & \\
\hline
\end{tabular}

a. Dependent Variable: Y

b. Predictors: (Constant), Z, X2, X1

The Sig column on Anova table, Sig Value is 0.000 or smaller than Prob Value 0.05 (Sig $0.000<0.050$ ), therefore, $\mathrm{H}_{0}$ is rejected and $\mathrm{H}_{\mathrm{a}}$ is accepted. It conclude that the variable of E-Trust $\left(\mathrm{X}_{1}\right)$, Website Quality $\left(\mathrm{X}_{2}\right)$ through E- Satisfaction $(\mathrm{Z})$ affect simultaneously and significantly to E-Loyalty (Y).

Table 2.3.9 Summary Sub-Structure 2

Model Summary ${ }^{b}$

\begin{tabular}{|c|c|c|c|c|}
\hline Model & $\mathrm{R}$ & $\mathrm{R}$ Square & Adjusted R Square & Std. Error of the Estimate \\
\hline 1 &, $855^{\mathrm{a}}$ &, 730 &, 725 & 1,414 \\
\hline
\end{tabular}

a. Predictors: (Constant), Z, X2, X1

b. Dependent Variable: Y

Simultaneously, the variable of E- Trust (X1), Website Quality (X2), and E- Satisfaction (Z) has contributed 73.0\% (R square Value) and on the Summary table describes the change on the variable of E- Loyalty (Y), meanwhile the rest $27.0 \%$ is described by the other variables. Anova table (F Test) shows that simultaneously the free variables affect significantly to the variable of E-Loyalty (Y) shown by the Sig Value $0.000<5 \%$.

Table 2.3.10 Coefficient Sub-Structure 2

\section{Coefficients ${ }^{\mathrm{a}}$}

\begin{tabular}{|c|c|c|c|c|c|c|c|}
\hline \multirow[t]{2}{*}{ Model } & \multicolumn{2}{|c|}{ Unstandardized Coefficients } & Standardized Coefficients & \multirow[t]{2}{*}{$\mathrm{t}$} & \multirow[t]{2}{*}{ Sig. } & \multicolumn{2}{|c|}{ Collinearity Statistics } \\
\hline & B & Std. Error & Beta & & & Tolerance & VIF \\
\hline (Constant) & $-2,725$ & 1,239 & & $-2,200$ & 029 & & \\
\hline $\mathrm{X} 1$ & , 128 &, 034 & ,233 & 3,737 & 000 & 457 & 2,187 \\
\hline $\mathrm{X} 2$ &, 172 & 041 & ,243 & 4,246 & 000 & ,541 & 1,848 \\
\hline Z & , 480 &, 067 & ,483 & 7,172 & 000 & 391 & 2,555 \\
\hline
\end{tabular}

a. Dependent Variable: Y

On the table 2.3.11, the variable of E- Trust $\left(\mathrm{X}_{1}\right)$, Website Quality $\left(\mathrm{X}_{2}\right)$ and E- Satisfaction $(\mathrm{Z})$ affect simultaneously to the E- Loyalty (Y) which intends to test Sig. constant and dependent variable. On coefficient table, T test / partial, it is seen that the variable of E-Trust $\left(\mathrm{X}_{1}\right)$ has value 0.000 higher than alpha $5 \%$ which means Sig Value or Ho is rejected and Ha is accepted. E-Trust $\left(\mathrm{X}_{1}\right)$, Website Quality $\left(\mathrm{X}_{2}\right)$ and E-Satisfaction $(\mathrm{Z})$ affect positively and significantly to the E-Loyalty $(\mathrm{Y})$, which is partially shown from each Sig. Value higher than Alpha $5 \%, 0.000$ and 0.000 .

$\mathrm{Y}=\rho y x_{1}+\rho y x_{2}+\rho y z+\varepsilon_{1}$

$$
=0,233 x_{1}+0,243 x_{2}+0,483 z+0,519 \varepsilon_{1}
$$

Table 2.3.11 Direct Effect

\begin{tabular}{|c|c|c|c|c|}
\hline Effect & Path coefficient & Standard Error & t-count & Sig. \\
\hline $\mathrm{X}_{1} \rightarrow \mathrm{Z}$ & 0,513 & 0,034 & 8,232 & 0,000 \\
\hline $\mathrm{X}_{2} \rightarrow \mathrm{Z}$ & 0,361 & 0,044 & 5,793 & 0,000 \\
\hline $\mathrm{X}_{1} \rightarrow \mathrm{Y}$ & 0,233 & 0,034 & 3,737 & 0,000 \\
\hline $\mathrm{X}_{2} \rightarrow \mathrm{Y}$ & 0,243 & 0,041 & 4,246 & 0,000 \\
\hline $\mathrm{Z} \rightarrow \mathrm{Y}$ & 0,483 & 0,067 & 7,172 & 0,000 \\
\hline
\end{tabular}

Keterangan: X1 = E-Trust, X2 = Website Quality, Z = E-Satisfaction, Y = E-Loyalty

Source: Data processed by the researcher, 2019

Beside using analysis in determining significance of intervening variable, to test sixth and seventh hypothesis, it could also use the measurement of Sobel Test with the formulation developed by Iman Ghozali (2011) below:

$$
z=\frac{a b}{\sqrt[3]{\left(b^{2} S E_{a}^{2}\right)+\left(a^{2} S E_{b}^{2}\right)}}
$$

When:

$\mathrm{a}=$ independent variable regression coefficient toward mediation variable

$\mathrm{b}=$ mediation variable regression coefficient toward dependent variable 
$\mathrm{SEa}=$ standard error of estimation from the effect of independent variable toward mediation variable $\mathrm{SEb}=$ Standard error of estimation from direct effect of E-Treust toward E-Satisfaction.

Table 2.3.12 Indirect Effect

\begin{tabular}{|c|c|c|c|c|}
\hline Effect & Path coefficient & Standard Error & t-count & Sig. \\
\hline $\mathrm{X}_{1} \rightarrow \mathrm{Z}$ & 0,513 & 0,034 & 8,232 & 0,000 \\
\hline $\mathrm{Z} \rightarrow \mathrm{Y}$ & 0,483 & 0,067 & 7,172 & 0,000 \\
\hline $\mathrm{X}_{1} \rightarrow \mathrm{Z} \rightarrow \mathrm{Y}$ & $\begin{array}{l}0,513 \times 0,483 \\
=0,248\end{array}$ & $\begin{array}{c}\sqrt{ }\left(0,513^{2} \times 0,067^{2}+0,483^{2} \times 0,034^{2}\right) \\
=0,038\end{array}$ & $\begin{array}{l}0,248 / 0,038 \\
=6,505\end{array}$ & 0,000 \\
\hline$X_{2} \rightarrow Z$ & 0,361 & 0,044 & 5.793 & 0,000 \\
\hline $\mathrm{Z} \rightarrow \mathrm{Y}$ & 0,483 & 0,067 & 7,172 & 0,000 \\
\hline $\mathrm{X}_{2} \rightarrow \mathrm{Z} \rightarrow \mathrm{Y}$ & $\begin{array}{l}0,361 \times 0,483 \\
=0,174\end{array}$ & $\begin{array}{c}\sqrt{ }\left(0,361^{2} \times 0,067^{2}+0,483^{2} \times 0,044^{2}\right) \\
=0,032\end{array}$ & $\begin{array}{l}\mathbf{0 , 1 7 4 / 0 , 0 3 2} \\
=5,415\end{array}$ & 0,000 \\
\hline
\end{tabular}

Keterangan: X1 = E-Trust, X2 = Website Quality, Z = E-Satisfaction, Y = E-Loyalty

Source: Data processed by the researcher, 2019

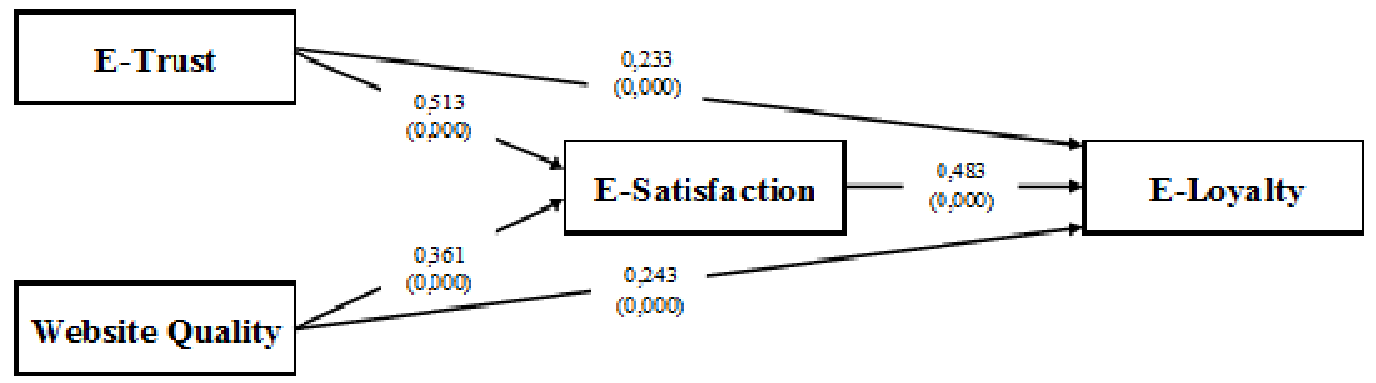

Figure 3.2 Analysis Results

Table 2.3.13 Results Analysis Path

\begin{tabular}{|c|c|c|c|c|}
\hline No. & Variable & Direct Effect & Indirect Effect & Total Effect \\
\hline 1 & $\mathrm{X}_{1} \rightarrow \mathrm{Z}$ & 0.513 & & 0.513 \\
\hline 2 & $\mathrm{X}_{2} \rightarrow \mathrm{Z}$ & 0.361 & & 0.361 \\
\hline 3 & $\mathrm{X}_{1} \rightarrow \mathrm{Y}$ & 0.233 & & 0.233 \\
\hline 4 & $\mathrm{X}_{2} \rightarrow \mathrm{Y}$ & 0.243 & & 0.243 \\
\hline 5 & $\mathrm{Z} \rightarrow \mathrm{Y}$ & 0.483 & & 0.483 \\
\hline 6 & $\mathrm{X}_{1} \rightarrow \mathrm{Z} \rightarrow \mathrm{Y}$ & & $0.513 \times 0.483=0.247779$ & $0.233+0.247779=0.480779$ \\
\hline 7 & $\mathrm{X}_{2} \rightarrow \mathrm{Z} \rightarrow \mathrm{Y}$ & & $0.361 \times 0.483=0.174363$ & $0.243+0.174363=0.417363$ \\
\hline
\end{tabular}

Source: Data processed by the researcher, 2019

1) The first Hypothesis test. The test of direct effect of E-Trust toward E-Satisfaction was obtained that t-count $(8,232)$ was bigger than t-table $(1,976)$ or Sig. $(0,000)$ was smaller than alpha $5 \%(0,050)$. This shows that there was a significant positive effect on E-Trust on E-Satisfaction.

2) The second hypothesis test. The test of direct effect of Website Quality toward E-Satisfaction was obtained t-count $(5,793)$ was bigger than t-table $(1,976)$ or Sig. $(0,000)$ was smaller than alpha $5 \%(0,050)$. This shows that there was a significant positive effect of Website Quality on E-Satisfaction.

3) The third hypothesis test. In the test direct effect of E-Satisfaction toward E-Loyalty, it was obtained that tcount (7.172) was bigger than t-table $(1.976)$ or Sig. $(0,000)$ was smaller than alpha $5 \%(0,050)$. This shows that there was a significant positive effect of E-Satisfaction on E-Loyalty.

4) The fourth hypothesis test. In the test of direct effect of E-Trust toward E-Loyalty, it was obtained that tcount (3.737) was bigger than t-table $(1.976)$ or Sig. $(0,000)$ was smaller than alpha $5 \%(0,050)$. This shows that there was a significant positive effect of E-Trust toward E-Loyalty.

5) The fifth hypothesis test. In the test of direct effect of Website Quality toward E-Loyalty, it was obtained that $\mathrm{t}$-count $(4,246)$ was bigger than $\mathrm{t}$-table $(1,976)$ or Sig. $(0,000)$ was smaller than alpha $5 \%(0,050)$. This shows that there was a significant positive effect of Website Quality toward E-Loyalty.

6) The sixth hypothesis test, In the test of direct effect of T-Trust toward E-Loyalty through E-Satisfaction, it was obtained that t-count $(6,505)$ was bigger than t-table $(1,976)$ or Sig. $(0,000)$ was smaller than alpha $5 \%$ (0.050), besides, the indirect effect of E-Trust on E-Loyalty through E-Satisfaction was resulted from the multiplication of the value of beta E-Trust (X1) toward E-Satisfaction (Z) with value beta E-Satisfaction (Z) toward E-Loyalty $(\mathrm{Y})$ which was $0.513 \times 0.483=0.247779$. Based on the calculations above, it is known that the indirect effect value is 0.247779 which means that the value of indirect influence is bigger than the value 
of direct influence. These results showed that there was a significant indirect effect on E-Loyalty through ESatisfaction as a intervening variable, so the sixth hypothesis was accepted.

7) The seventh hypothesis test. In the test of indirect Website Quality toward E-Loyalty through E-Satisfaction, it was obtained that t-count $(5,415)$ was bigger than t-table $(1,976)$ or Sig. $(0,000)$ was smaller than alpha $5 \%$ $(0,050)$. Other than that, Website Quality's indirect effect toward E-Loyalty through E-Satisfaction resulted from the multiplication of the beta value of Website Quality (X2) toward E-Satisfaction (Z) with beta value E-Satisfaction $(\mathrm{Z})$ toward E-Loyalty $(\mathrm{Y})$ was $0.361 \times 0.483=0.174363$. Based on the calculations above, it is known that the indirect effect value was 0.174363 which meant that the value of indirect effect was greater than the direct effect value. These results indicated that there was a significant indirect effect of Website Quality on E-Loyalty through E-Satisfaction as an intervening variable. Thus, the seventh hypothesis was accepted.

\section{Discussion}

a. The effect of E-Trust toward E-Satisfaction

The result of the research showed that there is positive and significant effect of E-Trust (X1) toward E-Satisfaction. It was proven that $\mathrm{t}$-count $(8,232)$ was bigger than t-table $(1,976)$ or Sig. $(0,000)$ was smaller than alpha $5 \%(0,050)$. it indicated that the higher the e-trust or the level of consumer confidence in the site, the higher the e-satisfaction or customer satisfaction with the site was. Conversely, the lower the e-trust, the lower the e-satisfaction was. This study supported previous studies of Kim et al. (2009) and Liao and Zhong (2013) which explained that there was a significant influence between e-trust and e-satisfaction.

b. The effect of Website Quality toward E-Satisfaction

The result of the research showed that there was positive and significant website quality (X2) toward E-Satisfaction (Z). This statement was proven by the value of t-count (5.793) which was than t-table $(1.976)$ or Sig. $(0,000)$ was smaller than alpha 5\% $(0,050)$. Thus, this study supported the previous study of Sadeh, et al. (2011) which stated that there was the positive and significant effect of website quality on customer satisfaction. Research was in line with Chen, et al. (2012) that website quality affected positively and significantly toward satisfaction.

c. The effect of E-Satisfaction toward E-Loyalty

The result of the research showed that there was positive and significant effect of E-Satisfaction $(\mathrm{Z})$ toward ELoyalty (Y). This statement was proven by the value of t-count (7.172) which was bigger than t-table (1.976) or Sig. $(0,000)$ was smaller than alpha $5 \%(0,050)$. Thus, this study supported the previous research examined that the E-Satisfaction variable had a significant and positive effect toward E-Loyalty. The results of this study were in line with the opinion of Kim et al. (2009) and Miguens et al. (2017) which stated that E-Satisfaction had a positive and significant effect toward E-Loyalty. The results of this study were also consistent with the research of Sadeh et al. (2011) which explained that E-loyalty was the most significant variable in online retailing that received the most effect from other variables, especially E-Satisfaction. Research from Anderson and Srinivasan (2011) also stated that e-satisfaction had a positive effect toward e-loyalty.

d. The direct effect of E-Trust toward E-Loyalty

In the figure of analysis, it was shown that there was direct effect of E-Trust toward E-Loyalty. It was obtained that tcount (3.737) was bigger than t-table (1.976) or Sig. $(0,000)$ was smaller than alpha $5 \%(0,050)$. Therefore, this study supported previous research of Kim et al. (2009) and Miguens et al. (2017) stated that E-Trust had a direct effect toward E-Loyalty. The results of the study were also in line with the research of Sadeh et al. (2011) and Siagian et al. (2014) which showed that E-Trust had a significant effect toward E-Loyalty.

e. The direct effect of Website Quality toward E-Loyalty

In the figure of analysis, it showed that there was direct effect of Website Quality toward E-loyalty. It was obtained that t-count value $(4,246)$ was bigger than t-table $(1,976)$ or Sig. $(0,000)$ was smaller than alpha $5 \%(0,050)$. Therefore, this study supported previous researchof Siagian et al. (2014) and O'cass \& Carlson (2012) stating that Website quality had a direct effect toward E-Loyalty. The results of the study were also in line with the results of a study from Puspitasari et al. (2013) and Bai et al. (2008) which stated that website quality proved to have a direct effect toward customer loyalty.

f. The indirect effect of Website Quality toward E-Loyalty through E-Satisfaction

In the figure of analysis, it showed that there was indirect effect of Website Quality through E-Satisfaction. It was obtained that $t$-count $(6,505)$ was bigger than t-table $(1,976)$ or Sig. $(0,000)$ as smaller than alpha $5 \%(0.050)$ and based on the multiplication calculation between beta values, it was known that the indirect effect value was 0.247779. it meant that the value of indirect influence was bigger than the value of the direct effect. It is concluded that there were significant indirect effects of E-Trust toward E-Loyalty through E-Satisfaction. These results indicated that Website Quality had an indirect influence on E-Loyalty through E-Satisfaction, or it can be concluded that E-satisfaction was a variable that mediated Website Quality toward E-Loyalty. This was in line with the research conducted by Bai et al. (2008) which revealed that the quality of a website affected loyalty through satisfaction. 
g. The Indirect effect of E-Trust toward E-Loyalty through E-Satisfaction

In the analysis figure, it showed that there was indirect effect of E-Trust toward E-Loyalty through E-Satisfaction. It was obtained that t-count $(5,415)$ was bigger than t-table $(1,976)$ or Sig. $(0,000)$ as smaller than alpha $5 \%(0.050)$. Based on the multiplication calculation between beta values, it is known that the indirect effect value was 0.174363 which meant that the value of indirect influence was bigger than the value of direct influence. Therefore, it is concluded that there were significant indirect effects on Website Quality towards E-Loyalty through E-Satisfaction. This showed that E-Satisfaction could be a variable that mediated E-Trust and E-Loyalty. The results of this study supported the study of Fitriani (2018) that there was an indirect influence between E-Trust toward E-Loyalty through E-Satisfaction.

\section{Conclusion}

Based on the results and discussion of the research about the effect of E-Trust, Website Quality toward E-Loyalty through E-Satisfaction as intervening variable of users of E-commerce C2C Tokopedia, it can be concluded as follow:

a. E-trust and Website Quality affect positively and significantly toward E-Satisfaction.

b. E-Trust, Website Quality and E-Satisfaction affect positively and significantly toward E-Loyalty.

c. E-Satisfaction can mediate directly and indirectly between E-Trust and Website Quality toward E-Loyalty.

\section{Recommendation}

a. Tokopedia is expected to be able to maintain and improve Website Quality by mentioning product information in detail and easy to understand in website, improve security regarding customer personal information, design menus that are easier to understand, improve website responsiveness, display more attractive and comfortable visual designs to see, complete transaction guidelines, and improve customer service. This is because the website quality variable has a significant effect toward customer E-Satisfaction and E-Loyalty.

b. Furthermore, it is to make E-trust and E-Satisfaction is going to increase and it gives impact on the enhancement of E-Loyalty. Tokopedia is expected to always improve the expertise and skills in serving customers, immediately be responsible if there is an error in the transaction and make every effort to listen and consider the suggestions submitted by the customer.

c. The further research is suggested to use other factors which can affect or add other variables such as word of mouth, repurchase intention or customer perception.

\section{References}

Anderson, R. E. dan S. Srinivasan. 2011. "Customer Satisfaction and Loyalty in e-markets: A PLS Path Modeling Approach". Journal of Marketing Theory and Practice. 19 (2), 221-234.

Bai, Billy, Rob Law and Ivan Wen. 2008. The Impact Of Website Quality On Customer Satisfaction And Purchase Intentions:Evidence From Chinese Online Visitors. International Journal Of Hospitality Management, 27: 391402.

Cheng Chuchu. 2014. "A Comprehensive Model of E-Loyalty: The Mediational Role of Customer Satisfaction”. Thesis. Faculty of The Graduate School of Arts and Science, Brandeis University.

Chia-Lin., Chang, Kuo-Chien, and Chen Mu-Chen. 2012. "The impact of website quality on customer satisfaction and purchase intention: perceived playfulness and perceived flow as mediators". Journal of Information Systems and e-Business Management. 10:549-570

Cooper, D.R., \& Schindler, P.A. 2014. Business Research Metehods. New York: McGraw-Hill

Creswell, J, W. 2013. Research Design Pendekatan Kualitatif, Kuantitatif, dan Mixed. Yogyakarta : Pustaka Pelajar.

Fitriani, A. (2018). Pengaruh E-Trust Dan E-Service Quality Terhadap E-Loyalty Dengan E-Satisfaction Sebagai Variabel Intervening (Studi Pada Pengguna E-Commerce C2C Shopee). Tesis. Fakultas Ekonomi Dan Bisnis Islam Uin Alauddin Makassar

Garbarino, E. dan M. S. Johnson. 1999. "The Different Roles of Satisfaction, Trust, and Commitment in Customer Relationship". Journal of Marketing. 63 (2), 70-87.

Gefen, D. 2000. "E-Commerce: The Role of Familiarity and Trust". Omega. 28 (6), 725-737.

Ghozali, Imam.2011. Aplikasi Analisis Multivariate Dengan Program IBM SPSS 17. Semarang: Universitas Diponegoro

Gregg, D.G. and Walczak, S. (2010). "The Relationship between Website Quality, Trust, and Price Premiums at Online Auctions". Journal ofElectronic Commerce Research.

Kim, J., B. Jin, dan J. L. Swinney. 2009. "The role of etail quality, e-satisfaction and e-trust in online loyalty development process". Journal of Retailing and Consumer Services. 16, 239-247.

Kim, J., B. Jin, dan J. L. Swinney. 2009. "The role of etail quality, e-satisfaction and e-trust in online loyalty 
development process". Journal of Retailing and Consumer Services. 16, 239-247.

Laudon, K. C. dan Traver, C. G. 2012. E-Commerce 2012: Business, Technology, Society. 8 ed. Kendallville: Pearson.

Liao L. dan J. Zhong. 2013. "Consumer Satisfaction, Trust and Loyalty in C2C Electronic Commerce". International Conference on Information Technology and Management Science (ICITMS 2012) Proceedings.

López-Miguens, M. J. and G. V. Encarnación, “An integral model of e-loyalty from the consumer's perspective”. Computers in Human Behavior, Vol. 72:397-411, 2017.

O'cass, Aron and J. Carlson. 2012. An e-retailing assessment of perceived website-service innovativeness: Implications for website quality evaluations, trust, loyalty and word of mouth. Australasian Marketing Journal,20, 28-36

Oliver, R. L. 1999. "Whence Consumer Loyalty”. Journal of Marketing. 63, 33-44.

Puspitasari et al. (2013). Pengaruh Kualitas Website Terhadap Nilai Yang Dipersepsikan, Kepuasan Dan Loyalitas Pelanggan Pada Online Shop. Jurnal Adminstrasi Bisnis. Vol.5, No.2, 1-9

Sadeh, E., L. Mousavi, M. Garkaz and S. Sadeh, (2011). The structural model of e-service quality, ecustomer satisfaction, trust, customer perceived value and e-loyalty. Aust. J. Basic Appl. Sci., 5(3): 532-538.

Sadeh, Mousavi, L. and Asgari, F. 2011. "The Effects of Website Quality Dimension on Customer Satisfaction in E-Retailing System" Middle East Journal of Scientific Research, Vol.10, No.3, 366-369.

Siagian, Hotlan dan Cahyono, Edwin. (2014). "Analisis Website Quality, Trust, dan Loyalty Pelanggan Online Shop". Jurnal Manajemen Pemasaran.

Sugiyono. 2014. Metode Penelitian Kuantitatif Kualitatif dan R\&D. Bandung: Alfabeta 